\title{
Main pathways of evolution of spermatozoa of Acoelomorpha and free-living Plathelminthes
}

\author{
E.E. Shafigullina, Ya.I. Zabotin \\ Kazan (Volga region) Federal University, Kazan, 420008, Russia. E-mail: \\ Shafigullina.EE@gmail.com
}

ABSTRACT: On the basis of original and literary data on ultrastructure of spermatozoa and their formation the reconstruction of main pathways of evolution of male gametes of Acoelomorpha and free-living Plathelminthes is proposed. Two species of Acoela Archaphanostoma agile and Convoluta convoluta - and five species of free-living flatworms from different taxa - Monocelis fusca, M. lineata (Proseriata), Uteriporus vulgaris (Tricladida, Maricola), Provortex karlingi (Rhabdocoela, Dalytyphloplanoida) and Macrorhynchus croceus (Rhabdocoela, Kalyptorhynchia) — have been investigated. Specimens were collected on the littoral zone of various islands of Keretskii Archipelago (White Sea), fixed in the $1 \%$ glutaraldehyde and studied with transmission electron microscope JEM 100 CX by the standard methodics. During the evolution of Acoela the axoneme formula of spermatozoa is modified and the position of free microtubules is reorganized. Evolutionary changes of spermatozoa of Plathelminthes are represented firstly by the locomotory apparatus (incorporation of flagellae, change of an axoneme formula and configurations of free microtubules), then by organization of nuclear material. And finally in specialized groups the oligomerization of mitochondria and additional inclusions occurs. In the spermiogenesis of Acoela and the advanced flatworms the specific peculiarities of ancestral forms, representing the examples of recapitulation on the cellular level, are described. The similarities and the differences of the sperm ultrastructure and spermiogenesis in Acoelomorpha and Plathelminthes are discussed in evolutionary-morphological aspect.

How to cite this article: Shafigullina E.E, Zabotin Ya.I. 2017. Main pathways of evolution of spermatozoa of Acoelomorpha and free-living Plathelminthes // Invert. Zool. Vol.14. No.1. P.59-66. doi: 10.15298/invertzool.14.1.09

KEY WORDS: Acoelomorpha, Plathelminthes, spermatozoa, ultrastructure, phylogeny.

\section{Основные пути эволюции сперматозоидов ацеломорф и свободноживущих плоских червей}

\section{E.E. Шафигуллина, Я.И. Заботин}

Казанский (Приволжский) федеральный университет, Казань, 420008, Pоссия. E-mail: Shafigullina.EE@gmail.com

РЕЗЮМЕ: В ходе данной работы на основе собственных и литературных данных по ультраструктуре сперматозоидов были прослежены основные тенденции в эволюции мужских половых клеток Acoelomorpha и свободноживущих плоских червей. Были исследованы два вида бескишечных турбеллярий (Acoela) - Archaphanostoma 
agile и Convoluta convoluta и пять видов свободноживущих плоских червей из разных отрядов - Monocelis fusca, M. lineata (Proseriata), Uteriporus vulgaris (Tricladida, Maricola), Provortex karlingi (Rhabdocoela, Dalytyphloplanoida) и Macrorhynchus croceus (Rhabdocoela, Kalyptorhynchia). Представители видов были собраны на литорали различных островов Керетского архипелага (Белое море), зафиксированы в 1\%-ном глютаровом альдегиде и исследованы с помощью трансмиссионного электронного микроскопа JEM 100 CX по стандартной методике. В ходе эволюции бескишечных турбеллярий изменяется формула аксонемы и расположение свободных микротрубочек. Эволюционные изменения сперматозоидов плоских червей в первую очередь затрагивают локомоторный аппарат (погружение жгутиков, изменение формулы аксонемы и конфигурации свободных микротрубочек), затем меняется организация ядерного материала. И наконец, в специализированных группах происходит олигомеризация митохондрий и дополнительных включений. Описаны особенности, свойственные предковым формам, проявляющиеся в ходе спермиогенеза Acoela и высокоорганизованных плоских червей, представляющие собой примеры рекапитуляции на клеточном уровне. Черты сходства и различия в ультраструктуре сперматозоидов и спермиогенеза Acoelomorpha и плоских червей обсуждаются в эволюционноморфологическом аспекте.

Как цитировать эту статью: Shafigullina E.E, Zabotin Ya.I. 2017. Main pathways of evolution of spermatozoa of Acoelomorpha and free-living Plathelminthes // Invert. Zool. Vol.14. No.1. P.59-66. doi: 10.15298/invertzool.14.1.09

КЛЮЧЕВЫЕ СЛОВА: Acoelomorpha, плоские черви, сперматозоиды, ультраструктура, филогения.

\section{Introduction}

The unique peculiarities of the structure of gametes are often used nowadays for phylogenetic analysis of various animal taxa (Reunov, Malakhov, 1993; Drozdov, Ivankov, 2000; Reunov, 2005) along with the other morphological features and molecular-genetic methods. In particular, the morphological diversity and complexity of reproductive system in flatworms greatly contrast with the relative simplicity of other tissues and organ systems. The first phylogenetic system of Plathelminthes proposed by Ehlers (1985) was based on the ultrastructural characters, including the sperm morphology. The free-living flatworms with ciliated epidermis known as "turbellarians" were shown to be an artificial paraphyletic group without the certain synapomorphies. So the ultrastructural characteristics of spermatozoa became the widespread tool for the reconstruction of phylogenetic relationships within the phylum Plathelm- inthes (e.g., Hendelberg, 1986; Justine, 1991; Raikova, 1991).

Later some authors supposed that three clades erected by Ehlers (1985) - Acoelomorpha, Catenulida and Rhabditophora - don't share a common origin, and therefore considered the phylum Plathelminthes the polyphyletic taxon (Smith et al., 1986; Carranza et al., 1997). RuizTrillo et al. (1999) separated Acoelomorpha from the flatworms on the basis of $18 \mathrm{~S}$ rDNA sequence data. But it should be notified that the molecular data of other authors (curiously, also based on $18 \mathrm{~S}$ rDNA sequence) confirmed the position of Acoela within the Plathelminthes (Campos et al., 1998; Giribet et al., 2000). At the present moment the Acoelomorpha are either joined with another enigmatic phylum Xenoturbellida within the superphylum Deuterostomia (Philippe et al., 2011), or the newlyerected taxon Xenacoelomorpha is considered to be the sister taxon to all remaining bilaterians (Cannon et al., 2016). Thus the phylogenetic 
relationships of Acoelomorpha and Plathelminthes still remain controversial and debatable.

The spermatozoa of majority of Plathelminthes (and Acoela as well) bear two free or incorporated axonemes (in Acoela they are incorporated) with the inverted position, which means that kinetosomes are located on the opposite cell pole from the nucleus (Hendelberg, 1986). The mode of spermiogenesis also differs in free-living and parasitic flatworms (Justine, 1991; Raikova, 1991). In the free-living flatworms the kinetosomes of axonemes turn around on $180^{\circ}$; the spermiogenesis of Neodermata is characterized by the migration of the nucleus into the distal part of spermatid and "proximodistal fusion" of axonemes with the cell body (Justine, 1991). This "neodermatan-type" spermiogenesis is considered a synapomorphy for the taxon Revertospermata, including Neodermata and parasitic "turbellarians" Fecampiida and Urastomidae (Kornakova, Joffe, 1999).

The aim of the present work is the electronmicroscopic investigation of the spermatozoa of selected species of Acoela and various taxa of free-living flatworms in the evolutionary-morphological aspect. The special attention has been paid to phylogenetically and taxonomically significant features of male gametes such as axoneme formula, position of flagella (incorporated or free), the configuration of cytoplasmic microtubules (axial or cortical), the structure of nuclear material, quantity and an arrangement of mitochondria and electron-dense granules and existence of other cytoplasmatic inclusions.

\section{Materials and methods}

Two species of Acoela - Archaphanostoma agile (Jensen, 1878) and Convoluta convoluta (Abildgaard, 1806) - and five species of free-living flatworms from different taxa -
Monocelis fusca Orsted, 1843, M. lineata (O.F. Muller, 1774) (Proseriata), Uteriporus vulgaris Bergendal, 1890 (Tricladida, Maricola), Provortex karlingi Ax, 1951 (Rhabdocoela, Dalytyphloplanoida), and Macrorhynchus croceus (O. Fabricius, 1826) (Rhabdocoela, Kalyptorhynchia) - have been investigated. Specimens were collected on the littoral zone of various islands of Keretskii Archipelago (White Sea, Russia), fixed in the $1 \%$ glutaraldehyde on $0.1 \mathrm{M}$ phosphate buffer, prepared for transmission electron microscopy by the standard methodics and studied with TEM JEM 100 CX.

\section{Results}

Spermatozoon of acoel Archaphanostoma agile is a long filiform cell with two incorporated axonemes (Fig. 1 A). The flake-like chromatin is evenly dispersed in the karyoplasm. Free cytoplasmic microtubules occupy the cortical position; the mitochondria and electron-dense granules are located in the middle region (neck) of spermatozoon. The axoneme structure can be described by "classical" formula $9+2$ or by the aberrant one $9+4$. In the latter case in the center of axoneme two additional hollow microtubulelike structures are located closely to the one of the singlets (Fig. $1 \mathrm{~A}, \mathrm{acm}$ ). The sperm is covered by the electron-dense external ornamentation (Fig. $1 \mathrm{~A}, e o$ ).

Spermatozoon of Convoluta convoluta contains two incorporated axonemes with formula $9+0$, but on the distal tip of the cell nearby the kinetosome their formula is changed into $9+2$ (Fig. 1 B). Free microtubules in mature sperm form a single axial cylinder, while in the spermatids the cortical microtubules instead of the axial ones have been found. A numerous mitochondria and dense granules are spread in the neck of spermatozoon.

\footnotetext{
Обозначения: a — аксонема; асm - дополнительные центральные микротрубочки (у A. agile); am — дополнительные микротрубочки (у U. vulgaris); cdc — центральный цилиндр; cm — кортикальные микротрубочки; ctm центральные микротрубочки; dfc — плотный волокнистый компонент кариоплазмы (у U. vulgaris); edg — электронно-плотные гранулы; ео — наружная орнаментация; $\mathrm{k}$ - кинетосома; $\mathrm{m}$ — митохондрия; $\mathrm{n}$ - ядро; pnc - перинуклеарное скопление (у P. karlingi); tc - прозрачный компонент кариоплазмы (у U. vulgaris). Черной пунктирной линией обозначены кончики ветвящихся жгутиков сперматозоидов U. vulgaris с микротрубочками. Масштаб: A, B, D, F-0,25 $\mu \mathrm{m} ; \mathrm{C}, \mathrm{E}-1 \mu \mathrm{m}$.
} 

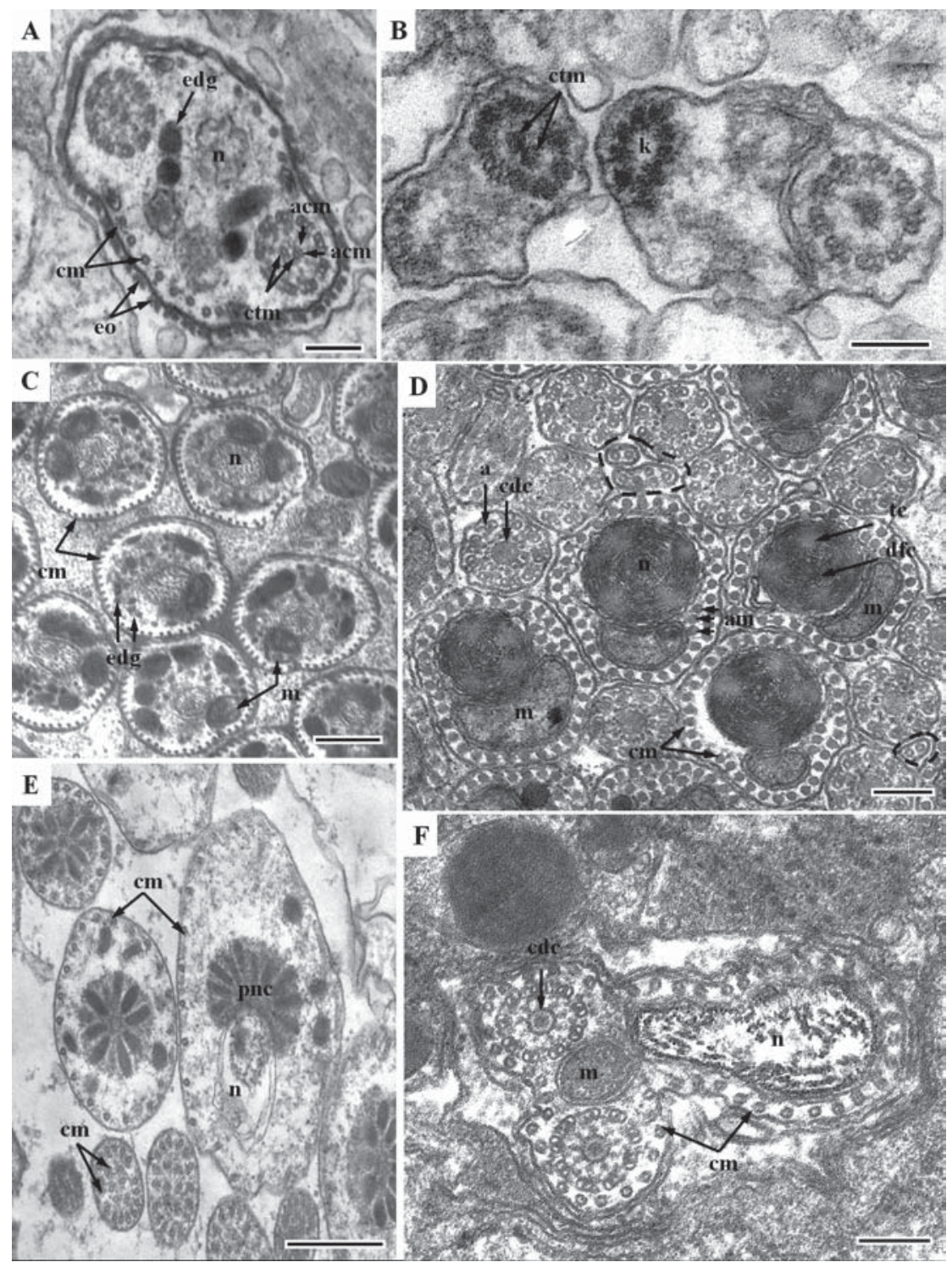

Fig. 1. The cross-sections of spermatozoa of Acoela and free-living Plathelminthes. A - Archaphanostoma agile; B - Convoluta convoluta; C - Monocelis lineata; D - Uteriporus vulgaris; E - Provortex karlingi; F - Macrorhynchus croceus.

Abbreviations: a — axoneme; acm — additional central microtubules (in A. agile); am — accessory microtubules (in $U$. vilgaris); cdc - central dense cylinder; $\mathrm{cm}$ - cortical microtubules; ctm - central microtubules; $\mathrm{dfc}$ - dense filamentous component of karyoplasm (in U. vulgaris); edg - electron dense granules; eo - external ornamentation; $\mathrm{k}$ - kinetosome; $\mathrm{m}$ - mitochondrion; $\mathrm{n}$ - nucleus; $\mathrm{pnc}$ - perinuclear condensation (in $P$. karlingi); tc — transparent component of karyoplasm (in U. vulgaris). Black dotted line marks the distal tips of the branched flagellae with microtubules in spermatozoa of $U$. vulgaris. Scale bars: A, B, D, F $-0.25 \mu \mathrm{m} ; \mathrm{C}, \mathrm{E}-1 \mu \mathrm{m}$.

Рис. 1. Поперечные срезы сперматозоидов бескишечных турбеллярий и свободноживущих плоских червей. A - Archaphanostoma agile; B - Convoluta convoluta; C — Monocelis lineata; D - Uteriporus vulgaris; E - Provortex karlingi; F — Macrorhynchus croceus. 
Proseriates Monocelis fusca and M. lineata are characterized by spermatozoa with two free (non-incorporated) flagellae with axoneme formula 9+"1" and cortical microtubules (Fig. 1 C). The nucleus contains a fibrous chromatin. The multiple mitochondria and dense granules are scattered in the middle part of spermatozoon.

Spermatozoon of Uteriporus vulgaris is organized typically for triclads and is characterized by the elongated nucleus, single mitochondrion and cortical microtubules (Fig. 1 D). The karyoplasm consists of two components: the dense filamentous one (chromatin) and the transparent one (probably of protein nature) coiled around each other in a screw-like pattern (Fig. 1 $\mathrm{D}, d f c, t c)$. Both free flagellae possess the axoneme formula 9+" 1 " and are branching dichotomically on the ends. The tip of each flagella splits into the long microvilli containing a few microtubules. A short row of three accessory microtubules separate the mitochondrion and the nucleus from the cortical microtubules (Fig. $1 \mathrm{D}, a m)$.

Spermatozoa of Provortex karlingi significantly differ from the other species studied by the absence of flagellae and the joining of electron-dense inclusions into the rosette-like structure known as perinuclear condensation (Fig. 1 $\mathrm{E}, p n c)$. In the middle part of sperm cell it partially surrounds the nucleus and becomes half-moon-shaped. The multiple mitochondria are also embedded into the perinuclear condensation. Despite the mature sperm of $P$. karling $i$ is lacking flagellae the spermatid contains the intercentiolar body. The position of free microtubules is a cortical.

The main volume of sperm of kalyptorhynchian Macrorhynchus croceus is occupied by the elongated nucleus and the single mitochondrion (Fig. 1 F). The chain of electron-dense granules passes alongside the nucleus and mitochondrion. The incorporated axonemes possess the formula 9+"1". The supportive apparatus of spermatozoon is formed by cortical microtubules.

\section{Discussion}

The ultrastructural features of spermatozoa of Acoela demonstrate the surprising diversity and are widely used in the taxonomy of this group (e.g., Raikova, Justine, 1994; Raikova et al., 1998; Petrov et al., 2004; Achatz et al., 2010; Jondelius et al., 2011; Haszprunar, 2016). For a long time the majority of acoel species, sometimes morphologically dissimilar, has been included into the family Convolutidae. Later, according to both molecular (18S rDNA sequence results) and morphological data (including the ultrastructure of spermatozoa) this artificial taxon was divided into two independent families (Petrov et al., 2004). The "large-bodied convolutids" with axial microtubules and axoneme formula $9+0$ have been left in the family with former name, while the "smallbodied convolutids" with the cortical microtubules and axoneme formula 9+2 have been grouped into the new family Isodiametridae (Hooge, Tyler, 2005). In particular, Archaphanostoma agile (formerly known as Baltalimania agile) also has been transferred into the latter family. The ultrastructure of its spermatozoa was previously described by Raikova and Justine (1994). The present work adds new data to their description, including the second type of axoneme of flagella, indicated as 9+4 (Zabotin, Golubev, 2011), that probably should be taken into account for the further phylogenetic constructions within the family Isodiametridae.

According to the modern phylogenetic analysis, the axoneme formula $9+2$ and the cortical microtubules are found in the spermatozoa of archaic families of Acoela and therefore represent the plesiomorphic condition for this taxon (Hooge, Tyler, 2005). The derived acoel families with atypical axoneme formulae (including the Convolutidae) form the taxon Aberrantospermata (Jondelius et al., 2011). In particular, the axoneme formula in convolutids is changing to $9+0$, while the free microtubules acquire the axial position (Achatz et al., 2010; Jondelius et al., 2011), which represents the apomorphic condition for Acoela. To our opinion, the rudimental pair of short central microtubules in the beginning of axoneme of Convoluta convoluta described here (Fig. 1 B) also supports the hypothesis of origin of $9+0$ axoneme from the classical 9+2 pattern. 
Evolutionary changes of spermatozoa of Plathelminthes are represented firstly by the locomotory apparatus: incorporation of flagellae, change of an axoneme formula and configurations of free microtubules. All flatworm species studied here belong to the taxon Trepaxonemata including the higher free-living flatworms and the parasitic taxa (Ehlers, 1985). The locomotory apparatus of their spermatozoa is rather conservative: two flagellae with axoneme formula 9+"1" (with a central electron dense cylinder instead of microtubules; Raikova, 1991) and cortical cytoplasmic microtubules. In various orders the flagellae can be incorporated, partially incorporated or free (Hendelberg, 1986). In some specialized taxa of Trepaxonemata the flagellae are completely lost, e.g. in the whole order Prolecithophora, a single monogenean family Diplozoidae and the several species of Proseriata and Rhabdocoela (Morrow, 2004). Particularly, within the latter taxon the aflagellate sperms were described in three species of the genus Provortex: P. balticus (Hendelberg, 1969), P. tubiferus (Sopott-Ehlers, Ehlers, 1995) and P. karlingi (Shafigullina et al., 2015). The apomorphic characters in Tricladida as one of the most advanced turbellarian orders also include the dichotomical branching of flagellae and the formation of the additional short row of microtubules between the cortical ones and the nucleus (Ishida et al., 1991; Chernova et al., 2014).

The next step of evolutionary transformations of male gametes of flatworms is the reorganization of nuclear material from the fibrous structures in the basal neoophorans Proseriata (exemplified here by Monocelis fusca and $M$. lineata) to the four dense longitudinal ribbons in karyoplasm of Tricladida (Ishida et al., 1991; Chernova et al., 2014).

Finally in specialized groups the oligomerization of mitochondria and additional inclusions in spermatozoa occurs. In Proseriata the numerous mitochondria and electron dense granules are chaotically dispersed in a middle region of spermatozoon. In the most specialized taxa of free-living flatworms (e.g., Kalyptorhynchia) the cellular inclusions merge into a chain along- side a nucleus. In two species of provorticids the oligomerization results in a formation of the perinuclear condensation of granules, which is involved into the specific morphofunctional associations with the nucleus and the single mitochondrion (Sopott-Ehlers, Ehlers, 1995; Shafigullina et al., 2015). In the spermatozoa of third species of this genus $P$. balticus, studied on light microscopic level (Hendelberg, 1969) this structure could not be distinguished.

In the spermiogenesis of the advanced Plathelminthes the specific peculiarities of ancestral forms are described. In particular, the recapitulation at the cellular level is exemplified by the development of the intercentriolar body - the cellular construction responsible for the formation of flagellae - in the spermatids of P. karlingi (Shafigullina et al., 2015). This structure was described previously in the related species $P$. tubiferus (Sopott-Ehlers, Ehlers, 1995), despite the mature spermatozoa of both these species are lacking flagellae.

It should be notified that the same evolutionary process is also described in Acoela. Particularly, the spermatids of $C$. convoluta contain the cortical microtubules (usually found in sperms of the primitive acoel families - see above) instead of the axial ones found in mature spermatozoa of Convolutidae (Chernova et al., 2012). Thus the process of reorganization of the free microtubules in convolutids recapitulates the evolutionary changes of locomotory apparatus of the entire taxon Acoela.

As a conclusion, it is worth returning to the problem of phylogenetic relationships of Acoelomorpha and Plathelminthes. As it was mentioned above, the most relevant molecular data separate these taxa and join Acoelomorpha with another enigmatic phylum Xenoturbellida into the basal bilaterian clade Xenacoelomorpha (Cannon et al., 2016). Nevertheless it should be notified that xenoturbellids significantly differ from acoels by the number of morphological characters including the primitive uniflagellate spermatozoa, the external insemination and the absence of copulatory organs (Obst et al., 2011). From the other side, the plesiomorphic (basal) condition of spermatozoa in Acoela and free- 
living flatworms is both characterized by the filiform biflagellate male gametes with the inverted position of flagellae, the axoneme formula $9+2$ and cortical microtubules. Further evolution of spermatozoa in these independent taxa leads to the totally different apomorphic conditions such as the "aberrantospermate" pattern of axonemes and axial microtubules in derived Acoela and "trepaxonemate" axoneme pattern with the conservation of cortical microtubules in Plathelminthes. The similar evolutionary-morphological processes such as abovementioned recapitulation of archaic characters during the spermiogenesis also take part on both these phyla. Despite in the modern phylogenetic constructions the main attention is undoubtedly paid to the molecular-genetic data, the morphological characters also should not be ignored. Particularly, to our opinion, the separation of Acoelomorpha and Plathelminthes, convincingly supported by the molecular data, also probably requires the sufficient ultrastructural proofs.

\section{References}

Achatz J.G., Hooge M., Wallberg A., Jondelius U., Tyler S. 2010. Systematic revision of acoels with $9+0$ sperm ultrastructure (Convolutida) and the influence of sexual conflict on morphology // Journal of Zoological Systematics and Evolutionary Research. Vol.48. No.1. P.9-32.

Campos A., Cummings M.P., Reyes J.L., Laclette J.P. 1998. Phylogenetic relationships of Platyhelminthes based on 18S ribosomal gene sequences // Molecular Phylogenetics and Evolution. Vol.10. No.1. P.1-10.

Cannon J.T., Vellutini B.C., Smith III J., Ronquist F., Jondelius U., Hejnol A. 2016. Xenacoelomorpha is the sister group to Nephrozoa // Nature. Vol.530. P.89-93.

Carranza S., Baguna J., Riutort M. 1997. Are the Platyhelminthes a monophyletic primitive group? An assessment using 18S rDNA sequences // Mol. Biol. Evol. Vol.14. No.5. P.485-497.

Chernova E.E., Zabotin Y.I., Golubev A.I. 2012. [Ultrastructure of gametes and their formation in the acoel turbellarian Convoluta convoluta (Acoela)]//Uchenye Zapiski Kazanskogo Universiteta. Seriya Estestvennye Nauki. Vol.154. No.2. P.129-138 [in Russian with English summary].

Chernova E.E., Zabotin Y.I., Golubev A.I. 2014. [Ultrastructure of gametes of marine tricladid Uteriporus vulgaris (Tricladida, Maricola)] // Zoologicheskii Zhurnal. Vol.93. No.3. P.401-411 [in Russian with English summary].
Drozdov A.L., Ivankov V.N. 2000. [Gamete morphology of animals. Meaning for systematic and phylogenetic]. Moscow: Kruglyi God. 460 p. [in Russian with English summary].

Ehlers U. 1985. Das Phylogenetische System der Plathelminthes. Stuttgart, New York: Gustav Fischer Verlag. $317 \mathrm{~s}$.

Giribet G., Distel D.L., Polz M., Sterrer W., Wheeler W.C. 2000. Triploblastic relationships with emphasis on the Acoelomates and the position of Gnathostomulida, Cycliophora, Plathelminthes and Chaetognatha: a combined approach from 18S rDNA and morphology // Systematic Biology. Vol.49. No.3. P.539-562.

Haszprunar G. 2016. Review of data for a morphological look on Xenacoelomorpha (Bilateria incertae sedis) / / Organisms Diversity and Evolution. Vol.16. P.363389.

Hendelberg J. 1969. On the development of different types of spermatozoa from spermatids with two flagella in the Turbellaria with remarks on the ultrastructure of the flagella // Zoologiska bidrag från Uppsala. Vol.38. P.1-50.

Hendelberg J. 1986. The phylogenetic significance of sperm morphology of Platyhelminthes // Hydrobiologia. Vol.132. P.53-58.

Hooge M., Tyler S. 2005. New tools for resolving phylogenies: a systematic revision of Convolutidae (Acoelomorpha, Acoela) // Journal of Zoological Systematics and Evolutionary Research. Vol.43. No.2. P.100-113.

Ishida S., Yamashita Y., Teshirogi W. 1991. Analytical studies of the ultrastructure and movement of the spermatozoa of fresh water triclads // Hydrobiologia. Vol.227. P.95-104.

Jondelius U., Wallberg A., Hooge A.M., Raikova O.I. 2011. How the worm got its pharynx: phylogeny, classification and bayesian assessment of character evolution in Acoela // Systematic Biology. Vol.60. No.6. P.845-871.

Justine J.-L. 1991. Phylogeny of parasitic Platyhelminthes: a critical study of synapomorphies proposed on the basis of the ultrastructure of spermiogenesis and spermatozoa // Canadian Journal of Zoology. Vol.69. P.1421-1440.

Kornakova E.E., Joffe B.I. 1999. A new variant of the neodermatan-type spermiogenesis in a parasitic 'turbellarian', Notentera ivanovi (Platyhelminthes) and the origin of the Neodermata // Acta Zoologica (Stockholm). Vol.80. P.135-151.

Morrow E.H. 2004. How the sperm lost its tail: the evolution of aflagellate sperm // Biological Review. Vol.79. P.795-814.

Obst M., Nakano H., Bourlat S.J., Thorndyke M.C., Telford M.J., Nyengaard J.R., Funch P. 2011. Spermatozoon ultrastructure of Xenoturbella bocki (Westblad 1949) // Acta Zoologica (Stockholm). Vol.92. P.109115.

Petrov A.A., Hooge M., Tyler S. 2004. Ultrastructure of sperms in Acoela (Acoelomorpha) and its concordance with molecular systematics // Invertebrate Biology. Vol.123. No.3. P.183-197. 
Philippe H., Brinkmann H., Copley R., Moroz L.L., Nakano H., Poustka A., Wallberg A., Peterson K., Telford M. 2011. Acoelomorph flatworms are deuterostomes related to Xenoturbella // Nature. Vol.470. P.255-258.

Raikova O.I. 1991. [On phylogenetic significance of turbellarian ultrastructural characters] // Trudy Zoologicheskogo Instituta AN SSSR. Vol.241. P.26-52 [in Russian with English summary].

Raikova O.I., Flyatchinskaya L.P., Justine J.-L. 1998. Acoel spermatozoa: ultrastructure and immunocytochemistry of tubulin // Hydrobiologia. Vol.383. P.207-214.

Raikova O.I., Justine J.-L. 1994. Ultrastructure of spermiogenesis and spermatozoa in three Acoels (Platyhelminthes) // Annales des Sciences Naturelles, Zoologie, Paris. Vol.15. P.63-75.

Reunov A.A. 2005. [Spermatogenesis of multicellular animals]. Moscow: Nauka. 123 p. [in Russian].

Reunov A.A., Malakhov V.V. 1993. [Evolution of structure of spermatozoa in invertebrates] // Uspekhi
Sovremennoi Biologii. Vol.113. No.1. P.3-18 [in Russian].

Shafigullina E.E., Gazizova G.R., Zabotin Y.I. 2015. [U1trastructure of afllagellate spermatozoa in rhabdocoel turbellarian Provortex karlingi (Neorhabdocoela, Dalyellioida)] // Zoologicheskii Zhurnal. Vol.94. No.11. P.1243-1248 [in Russian with English summary].

Smith J.P.S., Tyler S., Rieger R. 1986. Is the Turbellaria polyphyletic? // Hydrobiologia. Vol.132. P.13-21.

Sopott-Ehlers B., Ehlers U. 1995. Modified sperm ultrastructure and some data on spermiogenesis in Provortex tubiferus (Plathelminthes, Rhabdocoela): phylogenetic implications for the Dalyellioida // Zoomorphology. Vol.115. P.41-49.

Zabotin Y.I., Golubev A.I. 2011. [Ultrastructure of spermatozoa of four species of acoel flatworms and their significance for systematics] // Zoologicheskii Zhurnal. Vol.90. No.1. P.3-12 [in Russian with English summary].

Responsible editor E.N. Temereva 